\title{
MEASUREMENT OF BIOCARBON IN FLUE GASES USING ${ }^{14} \mathrm{C}$
}

\author{
K M Hämäläinen ${ }^{1,2} \bullet \mathrm{H} \mathrm{Jungner}^{1} \bullet \mathrm{O}^{\text {Antson }^{3}} \bullet \mathrm{J}$ Räsänen $^{3} \bullet \mathrm{K}$ Tormonen $^{3} \bullet \mathrm{J}^{\text {Roine }^{3}}$
}

\begin{abstract}
A preliminary investigation of the biocarbon fraction in carbon dioxide emissions of power plants using both fossil- and biobased fuels is presented. Calculation of the biocarbon fraction is based on radiocarbon content measured in power plant flue gases. Samples were collected directly from the chimneys into plastic sampling bags. The ${ }^{14} \mathrm{C}$ content in $\mathrm{CO}_{2}$ was measured by accelerator mass spectrometry (AMS). Flue gases from power plants that use natural gas, coal, wood chips, bark, plywood residue, sludge from the pulp factory, peat, and recovered fuel were measured. Among the selected plants, there was one that used only fossil fuel and one that used only biofuel; the other investigated plants burned mixtures of fuels. The results show that ${ }^{14} \mathrm{C}$ measurement provides the possibility to determine the ratio of bio and fossil fuel burned in power plants.
\end{abstract}

\section{INTRODUCTION}

Implementation of the emission trading system resulted in an urgent need to bring into practice an easily applied measurement method for quantifying the amount of biocarbon in the fuels burned in power plants. Presently, in Finland, bio- and fossil-based carbon dioxide $\left(\mathrm{CO}_{2}\right)$ amounts are usually calculated on the grounds of fuel consumption data and the $\mathrm{CO}_{2}$ coefficients, which are established for each fuel type separately. In the national regulations, there is also the possibility to define fractions with other methods. In this paper, we present an estimate as to what extent it is possible to determine the biocarbon fraction in the fuel used at the power plant via radiocarbon measurements of $\mathrm{CO}_{2}$ extracted from the flue gases.

The principle of discrimination between biobased and fossil carbon via ${ }^{14} \mathrm{C}$ measurements is well known (Clayton et al. 1955). Levin and Hesshaimer (2000) proposed that ${ }^{14} \mathrm{C}$ measurement in atmospheric air might be a useful tool for the validation of national fossil-fuel $\mathrm{CO}_{2}$ emissions, and ${ }^{14} \mathrm{C}$ measurements clearly can be used to trace fossil-fuel $\mathrm{CO}_{2}$ emissions into the atmosphere (Levin et al. 2003). In the United States, a standard method based on the same principle for identification of biobased content in manufactured materials was recently implemented (ASTM International 2005; Noakes et al. 2005; Norton and Devlin 2005). Also, aerosols deriving from bio and fossil sources are discriminated by the ${ }^{14} \mathrm{C}$ measurements (Currie et al. 1997; Slater et al. 2002; Szidat et al. 2004).

${ }^{14} \mathrm{C}$ content measured in flue gas makes it possible to assess fractions of bio and fossil fuel used in power plants because the difference of ${ }^{14} \mathrm{C}$ activity in the mentioned types of fuels exceeds $100 \mathrm{pMC}$. In renewable fuels, ${ }^{14} \mathrm{C}$ concentration varies today between $110-130 \mathrm{pMC}$, depending on the fuel type. This range was calculated for wood material with ages from 10 to $100 \mathrm{yr}$. The highest values were found for trees that were about $50 \mathrm{yr}$ old, while the lowest values are typical for biomaterial that has been formed in recent years. Our calculations were based on atmospheric ${ }^{14} \mathrm{C}$ data (Stuiver and Quay 1981; Levin et al. 1985; Levin and Kromer 1997, 2004) and on the assumption that each tree ring was equally wide. In Finland, the ${ }^{14} \mathrm{C}$ concentration range of wood material used as fuel is probably smaller than the range mentioned above because trees in cultivated forests are cut down at an age of 40-70 yr (Mielikäinen 1997), and only certain parts of the tree are used for energy production.

\footnotetext{
${ }^{1}$ Radiocarbon Dating Laboratory, University of Helsinki, Finland.

${ }^{2}$ Corresponding author. Email: Kai.Hamalainen@ @elsinki.fi.

${ }^{3}$ Technical Research Centre of Finland (VTT), Finland.
} 
The ${ }^{14} \mathrm{C}$ content in peat (which is not considered biofuel) varies depending on the age of the peat. If we assume that the energy of peat is $500-5730 \mathrm{yr}$ old, the ${ }^{14} \mathrm{C}$ content would be between $50 \mathrm{pMC}$ and $90 \mathrm{pMC}$. This variation causes serious difficulties in the determination of the biofuel content by the ${ }^{14} \mathrm{C}$ method at facilities burning peat.

\section{MATERIALS AND METHODS}

The samples were collected directly from holes in the power plant chimneys with a hollow metal rod. The gas sample was filtered with a quartz filter, dried in a freezer, and then closed in a 10-L Tedlar ${ }^{\circledR}$ sampling bag with a Teflon ${ }^{\circledR}$ valve. The sampling line and the filter were preheated in order to prevent condensation of moisture in the sampling line and filter. At power plant 1 , the sampling line was not preheated because the temperature of the flue gas was relatively low. Quartz filters were not used because solid particles are not generated during the burning of natural gas.

The sample bags were transported to the laboratory, where $\mathrm{CO}_{2}$ was cryogenically separated and collected. The $\mathrm{CO}_{2}$ concentration in the sampled flue gases was measured with a Fourier transformation infrared (FTIR) spectrometer. $\delta^{13} \mathrm{C}$ values were measured with an isotope ratio mass spectrometer (IRMS) from $\mathrm{CO}_{2}$. After $\delta^{13} \mathrm{C}$ measurement, the $\mathrm{CO}_{2}$ was reduced to graphite and pressed to a copper target (Slota et al. 1987). ${ }^{14} \mathrm{C}$ measurements were performed at the Uppsala AMS facilities.

Flue gases were collected from power plants using different kinds of fuels. One power plant (\#1) that uses only fossil fuel was chosen for our study in order to estimate the level of possible contamination during the sample preparation process (burning, sampling, and sample handling). We also tested the tightness of the plastic bag used for sampling with the samples from power plant 1 . The $\mathrm{CO}_{2}$ from sample 1 was purified immediately after sampling, while sample 2 was processed after 19 days of storage in a plastic sampling bag.

From power plant 2, which uses biobased fuel (bark and wood chips), samples were taken several times within a period of 3 months in order to determine the range of ${ }^{14} \mathrm{C}$ content in wood material used as fuel. In addition, we selected a log from a recently felled tree of known age, which was burnt in an open fireplace. Before burning, the wooden log was shattered into small pieces in order to homogenize the tested material; thus, the collected samples of $\mathrm{CO}_{2}$ represented the average isotopic composition of the wood. The ${ }^{14} \mathrm{C}$ concentration measured in generated $\mathrm{CO}_{2}$ delivered information on the average ${ }^{14} \mathrm{C}$ concentration in a tree of known age.

The other plants burned mixtures of different fuels. Fuel mixtures used at these plants are presented in Table 1. The information on the fuel composition at each power plant was obtained from staff members of the power plants. Power plant 3 was sampled once. From both power plants 4 and 5 , samples from 2 different fuel mixtures were collected. From power plant 5, parallel samples were also taken to ensure the results.

Table 1 Fuel mixtures used at investigated power plants.

\begin{tabular}{lcl}
\hline Power plant & Samples & Fuel \\
\hline 1 & $1-2$ & Natural gas (fossil methane) \\
2 & $3-10$ & Sawdust, wood chips \\
3 & 13 & Bark, sludge from paper factory, peat, and wood chips \\
4 & $14-15$ & Plastics, paper, coal, peat, construction waste, and wood chips \\
5 & $16-17$ & Bark, bio sludge, plywood residue, and wood chips \\
5 & $18-19$ & Bark, bio sludge, plywood residue, wood chips, and peat \\
Test log & $11-12$ & Wood \\
\hline
\end{tabular}




\section{RESULTS AND DISCUSSION}

Carbon dioxide concentrations in the samples collected from power plants were between 9-15\%, except for the samples collected at power plant 1 , where the concentration was only $3.1 \%$. Burning of the wooden $\log$ in a fireplace yielded an even lower $\mathrm{CO}_{2}$ concentration: $1.7 \%$.

The results in Table 2 show that the ${ }^{14} \mathrm{C}$ contamination over the whole process is low, and storage of samples in plastic sampling bags has only a minor influence on the result. The influence of atmospheric air contamination is lower when the measured ${ }^{14} \mathrm{C}$ concentration is close to the atmospheric value of ${ }^{14} \mathrm{C}$. The influence of atmospheric $\mathrm{CO}_{2}$ also depends on the $\mathrm{CO}_{2}$ concentration of the flue gas due to dilution. In samples with low $\mathrm{CO}_{2}$ concentration, the influence of atmospheric $\mathrm{CO}_{2}$ is more significant than in samples with high $\mathrm{CO}_{2}$ concentration.

Table $2{ }^{14} \mathrm{C}$ and $\delta^{13} \mathrm{C}$ signatures of $\mathrm{CO}_{2}$ in flue gas at power plant 1 , where only natural gas was burned. The $\mathrm{CO}_{2}$ of sample 1 was separated and collected immediately after sampling, while sample 2 was stored 19 days before the separation procedure.

\begin{tabular}{llrll}
\hline Sample & Date & Time & ${ }^{14} \mathrm{C}(\mathrm{pMC})$ & $\delta^{13} \mathrm{C}(\% \circ)$ \\
\hline 1 & 18 Aug 2005 & $9: 39$ & $1.1 \pm 0.3$ & -49.7 \\
2 & 18 Aug 2005 & $10: 00$ & $1.9 \pm 0.3$ & -48.6 \\
\hline
\end{tabular}

Reported $\delta^{13} \mathrm{C}$ values of natural gas $\left(\mathrm{CH}_{4}\right)$ range from $-21 \%$ o to $-76 \%$ (Deines 1980). In samples 1 and 2, the $\delta^{13} \mathrm{C}$ value of $\mathrm{CO}_{2}$ in flue gas is close to $-50 \%$, which is in the middle of the mentioned range. For coal and charcoal, $\delta^{13} \mathrm{C}$ ranges between $-20 \%$ and $-30 \%$ o. For wood of $\mathrm{C}_{3}$ plants, $\delta^{13} \mathrm{C}$ values fall into a similar range, while the most probable values are around $-26 \%$ o. In this case, the $\delta^{13} \mathrm{C}$ value may give some information as to the fuel types used.

At power plant $2,8{ }^{14} \mathrm{C}$ samples were collected from the flue gas within 3 months. From the results in Table 3, we can see that the ${ }^{14} \mathrm{C}$ concentration is quite constant. The average concentration for these values is $118.2 \mathrm{pMC}$, and the standard deviation is $1.4 \mathrm{pMC}$. The value is a bit lower than one might expect from the ${ }^{14} \mathrm{C}$ concentrations in air and the ages of the trees. The reason is probably the fuel material. Sawdust contains an average mixture of the whole tree material, whereas the wood chips contain mostly parts that have grown in recent years and thus have lower ${ }^{14} \mathrm{C}$ concentrations.

Table 3 Results for power plant 2. Fuel contained wood chips and sawdust.

\begin{tabular}{cllll}
\hline Sample & Date & Time & ${ }^{14} \mathrm{C}(\mathrm{pMC})$ & $\delta^{13} \mathrm{C}(\%)$ \\
\hline 3 & 08 Aug 2005 & $8: 38$ & $120.7 \pm 0.6$ & -26.4 \\
4 & 17 Nov 2005 & $7: 32$ & $119.8 \pm 0.5$ & -26.0 \\
5 & 22 Nov 2005 & $7: 29$ & $118.4 \pm 0.5$ & -26.1 \\
6 & 24 Nov 2005 & $7: 24$ & $117.5 \pm 0.5$ & -26.4 \\
7 & 29 Nov 2005 & $7: 20$ & $117.9 \pm 0.4$ & -25.9 \\
8 & 08 Dec 2005 & $7: 13$ & $117.5 \pm 0.4$ & -26.3 \\
9 & 14 Dec 2005 & $7: 12$ & $117.3 \pm 0.6$ & -26.4 \\
10 & 15 Dec 2005 & $7: 30$ & $116.4 \pm 0.6$ & -26.2 \\
\hline
\end{tabular}

A decreasing trend can be seen in the ${ }^{14} \mathrm{C}$ results in Table 3. A small part of this decrease might be due to the seasonal variation of atmospheric ${ }^{14} \mathrm{C}$ concentration (Levin and Kromer 1997; Kuc and Zimnoch 1998), but it cannot fully account for the decrease. $\mathrm{CO}_{2}$ concentrations in these samples 
were $9-15 \%$, so only a minor part of the measured ${ }^{14} \mathrm{C}$ originates from ambient air. Thus, the decrease in results must originate from the fuel used.

The test tree burnt in a fireplace was cut down in November 2005. Dendrochronology indicated that the tree had died in AD 2001 or 2003, and its age was estimated to be $73 \mathrm{yr}$. According to our calculations, the average ${ }^{14} \mathrm{C}$ concentration for this tree should be $127 \mathrm{pMC}$ (AD 2001) or 125 pMC (AD 2003). In our calculations, atmospheric ${ }^{14} \mathrm{C}$ data (Stuiver and Quay 1981; Levin et al. 1985; Levin and Kromer 1997, 2004) and the measured tree ring width data were used. The measured ${ }^{14} \mathrm{C}$ concentration was lower than estimated (Table 4), probably due to the incomplete burning process and unsuccessful homogenization of the wood material. Results from power plant 2 (Table 3 ) compared with the ${ }^{14} \mathrm{C}$ concentration in the test log show higher values for the $\log$, which indicates that the fuel burned at power plant 2 was composed of younger material.

Table 4 Results for $\mathrm{CO}_{2}$ obtained from burning a wooden log.

\begin{tabular}{lllll}
\hline Sample & Date & Time & ${ }^{14} \mathrm{C}(\mathrm{pMC})$ & $\delta^{13} \mathrm{C}(\% \mathrm{o})$ \\
\hline 11 & 20 Nov 2005 & $15: 14$ & $122.2 \pm 0.5$ & -23.7 \\
12 & 20 Nov 2005 & $15: 30$ & $121.8 \pm 0.5$ & -22.8 \\
\hline
\end{tabular}

The results for power plants 3-5 are presented in Table 5. The most accurate information on the fuel mixture was obtained at power plant 3 , where the carbon content of the used fuel was estimated to be bark $45 \%$, paper factory sludge $19 \%$, peat $28 \%$, and wood chips $8 \%$. Conversion factors of carbon content for different types of fuel were adopted after Alakangas (2000). If one uses the value of $118.2 \pm 0.6 \mathrm{pMC}$ for bark, sludge from a paper factory, and wood chips, the ${ }^{14} \mathrm{C}$ concentration of peat can be calculated assuming that the carbon fraction of each fuel type is known. Calculation gives a ${ }^{14} \mathrm{C}$ concentration of $68 \pm 4 \mathrm{pMC}$ for peat.

Table 5 Results for power plants 3-5, where different fuel mixtures were burned.

\begin{tabular}{llllrl}
\hline Power plant & Sample & Date & Time & ${ }^{14} \mathrm{C}(\mathrm{pMC})$ & $\delta^{13} \mathrm{C}(\% \circ)$ \\
\hline 3 & 13 & 17 Aug 2005 & $10: 00$ & $104.1 \pm 0.5$ & -26.4 \\
4 & 14 & 08 Sep 2005 & $11: 40$ & $70.9 \pm 0.3$ & -27.0 \\
4 & 15 & 09 Sep 2005 & $10: 00$ & $82.0 \pm 0.5$ & -26.7 \\
5 & 16 & 25 Sep 2005 & $12: 50$ & $119.1 \pm 0.5$ & -26.7 \\
5 & 17 & 25 Sep 2005 & $12: 58$ & $118.5 \pm 0.5$ & -27.1 \\
5 & 18 & 26 Sep 2005 & $15: 03$ & $95.7 \pm 0.4$ & -26.5 \\
5 & 19 & 26 Sep 2005 & $15: 10$ & $96.0 \pm 0.4$ & -26.7 \\
\hline
\end{tabular}

At power plant 4, 2 samples (14 and 15) were taken during normal operation on consecutive days. The staff from the power plant informed us that the fraction of coal and peat in the fuel mixture should be approximately the same in both samples. The moisture of solid recovered fuel (SRF) containing paper and plastics was measured each day: sample 14 (7.3\%); sample $15(15.1 \%)$. The difference could be a consequence of a bigger fraction of plastics in sample 14 than in sample 15 . The measured lower ${ }^{14} \mathrm{C}$ value of sample 14 supports this information since plastics are usually fossilbased material.

At power plant 5, the fuel burnt on 25 September (samples 16 and 17) was a mixture of bark, bio sludge, plywood residue, wood chips, and other wood-based fuels. The average ${ }^{14} \mathrm{C}$ content of this mixture is $118.8 \mathrm{pMC}$, which is in good agreement with the expected value for such a fuel mixture. 
Samples 18 and 19 were taken on 26 September, when peat was added to the fuel mixture, which is confirmed by the ${ }^{14} \mathrm{C}$ content. According to the information from the power plant staff, the power gained from peat and biofuels was 30-85 MW and 90-160 MW, respectively.

Adopting the ${ }^{14} \mathrm{C}$ concentration of $68 \pm 4 \mathrm{pMC}$ that we obtained at power plant 3 for peat, and 118.8 pMC for wood-based fuel (from determinations on samples 16 and 17), we can separately estimate electric power drawn from peat and wood-based fuel. Thus, the calculated minimum power from peat is $65 \mathrm{MW}$, while the maximum power from wood-based fuel is $123 \mathrm{MW}$. These estimates match the ranges given by the staff of the power plant investigated.

\section{CONCLUSIONS}

The ${ }^{14} \mathrm{C}$ signature of the $\mathrm{CO}_{2}$ present in flue gases enables quantification of the ratio of bio and fossil carbon in the fuel mixture. Influence from ambient air contamination in the method is low and can be taken into account when the results are calculated. The presented results point to the possibility of detecting even small changes in fuel mixtures, although the variation of ${ }^{14} \mathrm{C}$ concentration in biofuel and peat introduce uncertainty to the final results. Our study showed that the average ${ }^{14} \mathrm{C}$ concentration of wood-based fuel was 116-122 pMC at the investigated power plants. This range might be applicable for most wood-based fuels.

Application of the ${ }^{14} \mathrm{C}$ method for a fuel mixture containing peat is more problematic because ${ }^{14} \mathrm{C}$ content in this material is not well defined and varies according to the age of the peat. Our study allowed us to estimate ${ }^{14} \mathrm{C}$ concentration in peat used at the power plant; however, the obtained numeric value cannot be considered as constant and specific for power peat due to the wide range of age distribution found in peat deposits. Using the ${ }^{14} \mathrm{C}$ method to quantify the biocarbon fraction in fuel mixtures containing peat requires additional research work.

\section{ACKNOWLEDGMENTS}

The research was funded by the Finnish Funding Agency for Technology and Innovation (TEKES) within the Finnish ClimBus "Business Opportunities in Mitigating Climate Change" program. We would like to thank Mrs Anne-Maija Forss for skillful processing of the samples.

\section{REFERENCES}

Alakangas E. 2000. Suomessa Käytettäivien Polttoaineiden Ominaisuuksia [Properties of fuels used in Finland]. VTT Tiedotteita - Meddelanden - Research Notes 2045. Espoo: Technical Research Centre of Finland (VTT). $172 \mathrm{p}+$ appendix $17 \mathrm{p}$.

ASTM International. 2005. Method D 6866-05: Determining the biobased content of natural range materials using radiocarbon and isotope ratio mass spectrometry analysis. West Conshohocken, Pennsylvania, USA: ASTM International.

Clayton GD, Arnold JR, Patty FA. 1955. Determination of sources of particulate atmospheric carbon. Science 122(3173):751-3.

Currie LA, Eglinton TI, Benner BA, Pearson A. 1997. Radiocarbon "dating" of individual chemical compounds in atmospheric aerosol: first results comparing direct isotopic and multivariate statistical apportionment of specific polycyclic aromatic hydrocarbons. Nuclear Instruments and Methods in Physics Research B 123(1-4):475-86.
Deines P. 1980. The isotopic composition of reduced organic carbon. In: Fritz P, Fontes JCh, editors. Handbook of Environmental Isotope Geochemistry. Volume 1. The Terrestrial Environment A. New York: Elsevier. p 373-84.

Kuc T, Zimnoch M. 1998. Changes of the $\mathrm{CO}_{2}$ sources and sinks in a polluted urban area (southern Poland) over the last decade, derived from the carbon isotope composition. Radiocarbon 40(1):417-23.

Levin I, Hesshaimer V. 2000. Radiocarbon-a unique tracer of global carbon cycle dynamics. Radiocarbon 42(1):69-80.

Levin I, Kromer B. 1997. Twenty years of atmospheric ${ }^{14} \mathrm{CO}_{2}$ observations at Schauinsland station, Germany. Radiocarbon 39(2):205-18.

Levin I, Kromer B. 2004. The tropospheric ${ }^{14} \mathrm{CO}_{2}$ level in mid-latitudes of the Northern Hemisphere (19592003). Radiocarbon 46(3):1261-72.

Levin I, Kromer B, Schoch-Fischer H, Bruns M, Münnich M, Berdau D, Vogel JC, Münnich KO. 1985. 25 
years of tropospheric ${ }^{14} \mathrm{C}$ observations in Central Europe. Radiocarbon 27(1):1-19.

Levin I, Kromer B, Schmidt M, Sartorius H. 2003. A novel approach for independent budgeting of fossil fuel $\mathrm{CO}_{2}$ over Europe by ${ }^{14} \mathrm{CO}_{2}$ observations. Geophysical Research Letters 30(23):2194; doi:10.1029/ 2003 GL018477.

Mielikäinen K. 1997. Metsän kasvattaminen. In: Häyrynen M, editor. Tapion Taskukirja. 23rd edition. Jyväskylä: Metsätalouden kehittämiskeskus Tapio. p 204-15.

Noakes J, Norton G, Culp R, Nigam M, Dvoracek D. 2005. A comparison of analytical methods for the certification of biobased products. In: Chałupnik S, Schönhofer F, Noakes J, editors. LSC 2005: Advances in Liquid Scintillation Counting. Tucson: Radiocarbon. p 259-71.

Norton GA, Devlin SL. 2006. Determining the modern carbon content of biobased products using radiocarbon analysis. Biosource Technology 97(16):2084-90.
Slater JF, Currie LA, Dibb JE, Benner Jr BA. 2002. Distinguishing the relative contribution of fossil fuel and biomass combustion aerosols deposited at Summit, Greenland through isotopic and molecular characterization of insoluble carbon. Atmospheric Environment 36(28):4463-77.

Slota Jr PJ, Jull AJT, Linick TW, Toolin LJ. 1987. Preparation of small samples for ${ }^{14} \mathrm{C}$ accelerator targets by catalytic reduction of CO. Radiocarbon 29(2):303-6.

Stuiver M, Quay PD. 1981. Atmospheric ${ }^{14} \mathrm{C}$ changes resulting from fossil fuel $\mathrm{CO}_{2}$ release and cosmic ray flux variability. Earth and Planetary Science Letters 53(3):349-62.

Szidat S, Jenk TM, Gäggeler HW, Synal H-A, Fisseha R, Baltensperger U, Kalberer M, Samburova V, Reimann S, Kasper-Giebl A, Hajdas I. 2004. Radiocarbon $\left({ }^{14} \mathrm{C}\right)$-deduced biogenic and anthropogenic contributions to organic carbon (OC) of urban aerosols from Zürich, Switzerland. Atmospheric Environment 38(24):4035-44. 